\title{
Narrative foreclosure in later life: Preliminary considerations for a new sensitizing concept ${ }^{\text {th }}$
}

\author{
E.T. Bohlmeijer ${ }^{\text {a, }}$, G.J. Westerhof ${ }^{a}$, W. Randall ${ }^{\text {b }}$, T. Tromp ${ }^{c}$, G. Kenyon ${ }^{b}$ \\ a University of Twente, Enschede, Netherlands \\ b St. Thomas University, Fredericton, Canada \\ c Reliëf, Utrecht, Netherlands
}

\section{A R T I C L E I N F O}

\section{Article history:}

Received 25 August 2010

Received in revised form 16 December 2010

Accepted 21 January 2011

\section{Keywords:}

Narrative foreclosure

Identity development

Aging

Interdisciplinary

\begin{abstract}
A B S T R A C T
The objective of the paper is to explore narrative foreclosure as a sensitizing concept for studying the ways in which narrative identity development falters in later life. Two main characters in famous movies are contrasted to provide a better understanding of narrative foreclosure. The concept is further clarified by discussing similarities and differences with other theories about lifespan identity development. Last, the concept is related to theories in social gerontology to provide a better understanding of narrative foreclosure in later life.

It is concluded that narrative foreclosure can be defined as the conviction that no new interpretations of one's past nor new commitments and experiences in one's future are possible that can substantially change one's life-story. In terms of the metaphor of a book, one is not only convinced about its ending and does not add new chapters anymore, but also refrains from enjoying, rewriting, and editing earlier chapters. Several interpersonal-social and structuralideological factors are identified that promote narrative foreclosure in later life.

Finally it is discussed that the narrative study of later life and of narrative foreclosure in particular, should be conducted in an interdisciplinary framework. Narrative foreclosure only exists within a certain constellation of personal, social, and societal characteristics, drawn together in a mutually dependent system.
\end{abstract}

(c) 2011 Elsevier Inc. All rights reserved.

\section{Introduction}

There has been a growing interest in narrative perspectives in human sciences in general and in social gerontology in particular. Narrative gerontology is a discipline that explores how aging individuals give meaning to their lives by studying how they "story" their lives. Hence, the internal dynamics of aging are central: its "biographical" or "inside" dynamics (Birren, Kenyon, Ruth, Schroots, \& Svensson, 1996; Kenyon, Bohlmeijer, \& Randall, 2011).

\footnotetext{
Winner of the 2009 theoretical developments in social gerontology award.

* Corresponding author at: University of Twente, Faculty of Behavioral Sciences, Department of psychology, Postbus 217, 7500 AE Enschede, Netherlands. Tel.: + 31651070348 .

E-mail address: e.t.bohlmeijer@utwente.nl (E.T. Bohlmeijer).
}

These narrative perspectives claim that humans are hermeneutical beings. We make meaning to live and we need meaning to survive (Reker \& Chamberlain, 2000). Moreover, immersed as we are in both language and time, narrative is our main means of fashioning it (Bruner, 1990; Polkinghorne, 1998; Ricoeur, 1991). Central is also the notion that self is a narrative process. It is "not a static thing nor a substance", but "a single unfolding and developing story" (Polkinghorne, 1998). Or, put another way, narrative identity is "an individual's internalized, evolving, and integrative story of the self" (McAdams, 2008).

A central premise of narrative gerontology is that identity development and meaning making must be seen as a lifelong process (Kenyon, Clark, \& de Vries, 2001). Essential for narrative development is what they (Randall \& McKim, 2008) called "reading our lives". Reading our lives, i.e., examining our lives, and rewriting our past are prerequisites, they argue, for finding 
new meanings in life. Narrative development is therefore "a potentially infinite process" (Freeman, 1991, p. 90).

Yet, some people at some point in time might come to belief that the story of their life is over. Psychologist Mark Freeman (2000) coined the term narrative foreclosure (NF) to describe this belief. For him, NF is "the premature conviction that one's life story has effectively ended" (p. 83). It is the "unshakable conviction that it is simply too late to live meaningfully" (p. 83). NF implies that one already knows the ending of one's life. No other alternative endings are considered as realistic. Necessarily, this also shapes the story of one's past: "there is little left to do but play out the pre-scripted ending” (p. 83). In a similar vein, Brockmeier (2000) distinguished static narratives. These narratives are "timeless" in that they tend not to see life as a movement or a process. Similarly, Morson (1994, p. 193) speaks of "epilogue time", which implies that "no present action could make any real difference" (p. 192) and that "the important story is over, nothing essential will change" (p. 190).

We believe that narrative foreclosure is a problematic phenomenon, because one of the most basic aspects of human life, the capacity to reflect on it and attribute meaning to it, seems impaired. In this paper we want to further explore narrative foreclosure (NF) as a sensitizing concept for studying how narrative development falters in later life. First, to provide a better understanding of the concept NF, we will contrast two examples of main characters in famous movies. Next, the concept will be elucidated by distinguishing it from normal identity development across the lifespan. Last, we will relate NF to important theories in social gerontology to get a better understanding of possible causes of NF in later life.

\section{Two case studies of contrasting movie characters}

Contrasting examples from two famous movies raise some new questions about the nature of narrative foreclosure: "The Remains of the Day" (1993), based on a novel of JapaneseBritish author Kazuo Ishiguro, and directed by James Ivory; and the Japanese movie 'Ikiru' (1956), directed by Akira Kurosawa.

In "The Remains of the Day", Anthony Hopkins plays the main character: Mr. Stevens, who works as the butler of Darlington Hall in the late 1930s. The movie is set against the background of the start of the Second World War, with Lord Darlington himself having close ties to Nazi Germany. Stevens is a very able butler whose main concern is that order and tradition prevail at Darlington Hall. When short on staff, a new housekeeper is hired: Miss Kenton, played by Emma Thompson. It soon becomes clear that Miss Kenton has fallen in love with Mr. Stevens. For Stevens, however, love is a nontopic. Beautiful young women who apply for positions at Darlington Hall are always rejected because they could only distract him from his duties. In a very comical yet tragic scene, Kenton finds out that in his (very spare) spare time, Stevens reads romantic novels. However, he is very embarrassed by this discovery. "Why do you always hide what you feel?" Miss Kenton asks. Stevens declares that he reads such stories in order to "further my education on the correct use of the English language". At this moment the two are standing close together and there is the possibility of them kissing. This is not to be. The story continues, but Miss Kenton's feelings remain unspoken and unanswered. In despair, she decides to marry another butler with whom she starts a bed and breakfast in Clevedon on the English West coast. Many years after the war, Stevens travels to Clevedon to meet Miss Kenton, now divorced, in hopes she will consider returning to Darlington Hall as a housekeeper. Once more, the viewer feels there is the possibility for love. Kenton, however, wants to stay close to her daughter, who is pregnant, while for Stevens it is "work, work, work and it will continue to be so".

Stevens' identity revolves around his story as a butler. His father has been a butler as well and he strives to fulfill this role to perfection. Interestingly, he is able to review part of this story by admitting his failures in following Lord Darlington and his sympathy for Nazi Germany. Yet, in what remains of the day, he will always be fully immersed in his story as a butler. He is not able to open up the chapter of love. In this sense, he can be said to be narratively foreclosed.

How different things are for Mr. Kanji Watanabe in the movie Ikiru (which, in English, means To Live). Watanabe is section chief of the department of public affairs in the city council. Life in the department is all about bureaucracy. Watanabe lives with his son and daughter-in-law, but some quick scenes clarify that the relationship is very distanced and cold. His son is merely waiting for him to die so that he can inherit the pension Watanabe has saved during his 35 years of working. Then something unexpected happens. Watanabe is diagnosed with incurable stomach cancer. He is so upset that he no longer shows up for work and even stays away from home as well. He meets a poet and then, later, a young female colleague from work. In their company he gets drunk, only to find the pleasures of the nightlife rapidly depleting his savings. Eventually, the female colleague has enough of him and leaves him alone. Finally going home, Watanabe tries to talk with his son, but his son gives him a difficult time for spending his pension.

Watanabe's life appears to be heading for complete loneliness and despair. But in the end, he is inspired by the opportunity to take a risk and change it all. During the last year of his life, he puts all his effort and his patience into a new project: the construction of a new square in an area of the city where there is now only dirt and squalor. And he is successful: the square is built. One winter day, while sitting on the square, he freezes to death. Yet he dies as a perfectly happy man.

In narrative terms, Watanabe first has to tell himself a story of an irrevocably lost life that seems impossible to change. Narrative foreclosure seems to be complete. But in the end he allows himself the freedom to add a new chapter to his life. At the very last moment he realizes that the story of his life has not really ended. Even though he is close to death, he is able to open up his story and act accordingly.

The contrasts between these two movie characters raise a number of questions with regard to narrative development. For Freeman, narrative foreclosure has a negative connotation, and implies depression and bitterness. The story of Watanabe was foreclosed in this sense too as his life seemed miserable and depressed. In contrast, by identifying so closely with his role as butler, Stevens remained stuck in his past and was unable to open up new possibilities for a life filled with love. This raises the question, then, as to when it is that stability and continuity in identity can be described as narrative foreclosure. To shed 
light on this question we discuss how narrative foreclosure differs from normal lifespan identity development in the following section.

One further point of contrast is that Watanabe was able to open up after experiencing a crisis, even though the end of his life was approaching fast. Mr. Stevens, however, had been foreclosed throughout his adult life, and not just in old age. The contrasting processes that these characters have gone through raise the question, then, as to the relation between $\mathrm{NF}$ and aging. To help answer this question, we will discuss different social gerontological theories that help to understand narrative foreclosure in later life.

\section{Narrative foreclosure and identity development}

McAdams $(1996,2008)$ has developed a life story model of personality with three operating levels. Level 1 consists of decontextualized personality traits; which is to say, general inclinations to behave in a specific way, irrespective of the situation at hand (e.g. the so-called "big five" traits of Neuroticism, Extraversion, Openness, Conscientiousness, and Agreeableness). Level 2 consists of personal concerns that are contextualized in time, place, and social roles (e.g. personal striving, life-tasks, and coping strategies). Level 3 consists of evolving life-stories that integrate past, present and future. At this third level, a selfing process is going on in which the I is constantly creating a Me. In McAdams (1996, p. 302) words, "The process of selfing involves constructing and authoring experience as one's own, as well as appropriating, synthesing, reflecting on, and simply observing experience in such a way that it is deemed to be mine". This selfing process thus gives unity and purpose to one's life and is storied by nature. Without the integrating function of life-stories, in other words, one would experience one's life as scattered and random.

A life story is always authored both by the person him- or herself and by the culture within which he or she lives. As McAdams (2008 p. 243) puts it: "The self comes to terms with society through narrative identity”. A life story, moreover, integrates the experienced present, the reconstructed past, and the anticipated future (McAdams, 2008). By analyzing the process of life-story telling on the basis of life story interviews, it is possible to determine the characteristics of a person's self-identity at that moment. Its structure and content can be understood in terms of such features as narrative tone, ideological setting, themes, images, and endings (McAdams, 1996). Among the criteria of a "good" life-story that have been advanced are: coherence, credibility, differentiation, openness, and generativity. When these criteria are substantially present in life-stories, i.e., not too much and not too little, it is possible to integrate new experiences, to cope with transitions and losses, and to develop new meanings and storylines. A "good" life-story thus allows stories to change over time: "An open story propels the person into the future by holding open a number of different alternatives for future action and thought" (McAdams, 1996 p. 315). This is all the more important as narrative identity "remains a project to be worked on for much of the rest of the life course" (McAdams, 2008, p. 252).

It is commonly assumed that a narrative identity is first constructed in late adolescence and young adulthood (Erikson, 1968; Habermas \& Bluck, 2000). Marcia (1966) distinguished between exploration and commitment as processes of identity development which lead to four different identity statuses: diffusion, foreclosure, moratorium, and achievement. Diffuse persons show a lack of identity commitments and no interest in a process of exploration to achieve these commitments. Foreclosed persons have strong identity commitments but without a process of individual exploration, such as when they take over parental values without discussing or critiquing them. Moratorium persons are actively exploring alternative selfidentities but have no firm commitments as yet. When persons have committed themselves to a stable system of beliefs, values, and goals after a period of exploration, they have adopted the status of achievement.

There has been growing recognition that exploration and commitment are lifelong processes (Grotevant \& Cooper, 1986; Stephen, Fraser, \& Marcia, 1992). Marcia (1980, p. 160) states that "resolution of the identity crisis at adolescence guarantees only that one will be faced with subsequent identity crises. A well-developed identity structure is flexible." Marcia (1980) described lifespan identity development in terms of alternating cycles of moratorium and achievement (MAMA). Whereas stable periods are characterized by the maintenance of identity structure, major life events ask for exploration processes in which identity structures are open to change and revision.

Whitbourne (1986) developed an identity process theory that may be especially suited for middle and later adulthood. She defined three identity processes (Skultety \& Whitbourne, 2004). Identity assimilation is aimed at maintaining a sense of self-consistency by selecting and interpreting information that is consistent with current self-schemata. This may involve ego-defensive processes such as denial. Identity accommodation is aimed at changing the self in response to new experiences. In the extreme, there is no stable, consistent self-identity and those who dominantly rely on this process are highly responsive to external influences. Whitbourne's position is that the flexible use of both styles, which she calls identity balance, is most beneficial to identity development. "Identity balance individuals are in the best position to age successfully because they can flexibly adapt and integrate age-related changes while simultaneously retaining a sense of inner consistency and stability" (Skultety \& Whitbourne, 2004; p. 33).

Bringing a narrative perspective to these theories on identity development, Westerhof $(2005,2009)$ and Westerhof, Bohlmeijer, van Beljouw, and Pot (2010) have argued that the identity processes of maintenance of structure and openness to change can be studied in relation to older adults' life stories. In a study on retirement in times of cultural change, he found that some individuals are more inclined than others to incorporate cultural change in their life narratives and that this was also related to the way they construed their retirement. Individuals who saw themselves as more modern were also the ones who were exploring new possibilities in their present phase of life, whereas those who clung most to the past were more likely to see their retirement as a continuation of, or epilogue to, their past life.

We conclude that current developmental theories define the development of self-identity as a life-long process of narrative construction. They all propose that a balance between continuity and flexibility in identity processes guarantees an 
optimal development. Continuity in commitment to values, meanings, and plans enables one to direct one's life. Flexibility enables one to integrate new experiences that come with change and to explore alternative meanings and commitments. In some periods in an individual's life, commitment may prevail; in other periods, exploration may prevail. In narrative terms, storying is the process in which the I is constantly and, most of the time, gradually constructing a Me.

\section{Definition of narrative foreclosure}

This brief, by no means exclusive, description of the narrative process of identity construction throughout the lifespan helps us to further describe how narrative foreclosure is different from normal identity development in three ways. First, we propose that the selfing process is normally experienced as an ongoing meaningful project as long as there is a balance between narrative stability and openness. Narrative foreclosure is characterized by an exclusive focus on existing commitments and identity structures and by a lack of openness towards change. Narrative foreclosure can therefore be defined as the conviction that no new experiences, interpretations, and commitments are possible that can substantially change one's life-story and the meaning of one's life as it is told now. In other words, the normal narrative process of selfing has stopped.

Second, given that a good life story provides temporal integration by reviewing one's past and anticipating one's future, we propose that narrative foreclosure lacks this kind of integration. The conviction is that there are no more meaningful commitments and experiences in the future. NF will also be characterized by a lack of agency in one's story, implying a lack of hope and self-efficacy in realizing one's goals. As long as the future is foreclosed, so is the past. With regards to the past, narratives might assume either the form of obsessive reminiscence about episodes in the past that went wrong or escapist reminiscence in the sense of excessive nostalgia (Wong, 1995). Autobiographical reasoning in the sense of an active life reviewing which involves reinterpretations of past events, is not considered a meaningful and helpful activity in creating a life story anymore. In terms of the metaphor of a book, one is no longer in the process of writing one's life-story: one is convinced about its ending and does not add new chapters anymore, but also refrains from enjoying, rewriting, and editing earlier chapters.

Third, narrative foreclosure differs from a normal concern about stability and continuity. In some phases of their lives, individuals may be open to new experiences and to a process of rewriting their lives. In other phases, they may be content with their commitments and achievements. They will mainly see their lives in terms of continuity and they will be inclined to interpret their past, present, and future in terms of already established identity structures. This kind of narrative may be experienced positively when one has found important commitments in life, when one has accomplished the goals one had in one's life, or when it results from a process of lifereview that effectively ended with a sense of ego-integrity (Butler, 1963; Erikson, 1950). However, this narrative stability does not mean that the selfing process has stopped: even the maintenance of a stable identity involves a process of interpretation and meaning making (Westerhof, 2009). In this sense, the story of Mr. Stevens from "The Remains of the Day" is partly a story of firm commitments to one domain of life - work - and partly a story of narrative foreclosure in another domain - love.

However, when one did not live the life one had wished or hoped for, when one did not develop one's identity by committing to meaningful and authentic values, and when one is convinced that it is impossible or too late to make any changes, a negative experience of narrative foreclosure might result, rather than a positive sense of closure. Narrative foreclosure is thus characterized by a strong wish to rewrite one's past or change one's life direction, yet at the same time, by the realization that one does not really know how.

\section{Narrative foreclosure and theories of aging}

The contrast between the two movies we discussed earlier - the Remains of the Day and Ikiru - also raised questions regarding the relation between NF and aging. In other words, what might be causes of narrative foreclosure in later life. Building on the theories on identitity development discussed earlier in this article, we believe that NF is generally at stake at turning points in the human life course. The narratives which normally undergird stability and continuity in one's identity commitments are challenged when a person experiences a critical turning point, e.g., moving to another city, retirement, the loss of a loved one, decline in one's health and autonomy. This situation provides not only new experiences, but also questions the underlying narrative schemes. Different factors might contribute to the experience that one is not able to provide meaningful answers to the questions raised by reviewing one's past or reconsidering one's future. In other words, the process of selfing might get stuck and NF will develop.

We will now discuss some of the factors that might contribute to NF from various perspectives. One may hypothesize that personal-psychological factors predict NF, e.g. from Erikson's (1982) epigenetic theory about the resolution of psychosocial crises or from McAdams' (1996, 2008) theory about the different levels of personality. Within the scope of this article we will focus on social gerontological theories which draw our attention to interpersonal-social factors and structural-ideological factors that might be related to NF.

\section{Interpersonal-social factors}

NF is more than the result of a personal interpretation of one's life, given the role of "narrative environment" in forming life stories (Randall \& McKim, 2008). The people among whom individuals grow old can be seen as coauthors of the stories they live by. In this respect, it can occur that key people foreclose on older adults, so delimiting or dominating their narrative development - telling them in so many ways what to think and do, insisting that their version of old age is the version of old age - that, effectively, older adults' stories are not their own. In that case, other people do not co-author narrative identity so much as co-opts it.

Discursive theories of aging are most informative in this regard (Westerhof \& Tulle, 2007; Williams \& Nussbaum, 2001). These theories contend that "communicative patterns can be counterproductive in both the long and short terms, in 
that they can reproduce negative attitudes toward aging as well as inhibit successful aging" (Giles, Coupland, Coupland, Williams, \& Nussbaum, 1992, p. 271). Such counterproductive communication depends at least in part on the activation of stereotypes about older persons. Stereotypes about older persons tend to be mixed: they are generally seen as warm on the interpersonal side but as incompetent in terms of physical and cognitive functioning (Cuddy \& Fiske, 2001; Kite \& Johnson, 1988). The enactment of these stereotypes results in paternalistic behaviors which have also been described as patronizing speech (Ryan, Hummert, \& Boich, 1995), displaced baby talk (Caporael \& Culbertson, 1986), or elderspeak (Kemper \& Harden, 1999). Williams and Nussbaum (2001) characterize this communication style as overaccommodative: the behavior is guided more by one's own expectations about the older person than by the needs of this person. The stereotype activation model (Hummert, 1994) makes clear that the enactment of stereotypes in overaccommodative communication styles depends on characteristics of the interlocutor (e.g. age and previous intergenerational experiences), the older person him- or herself (e.g., physique and personal appearance), and the salience of age in the situation at hand (e.g., competition between younger and older job applicants or an age-homogenous environment like nursing homes).

Long-term care institutions, for example, provide a formal environment, in which many characteristics referred to in the stereotype activation model come together. Based on her literature review Grainger (2004) concluded that absence of talk characterizes many interactions between nurses and residents. "The knowledge that there is a paucity of social interaction in nursing homes for seniors should serve as a part of an entire picture in which any talk that does take place becomes all the more meaningful because of its rarity" (Grainger, 2004, p. 482). Whenever there is communication, it tends to be centred on care tasks around the residents' body (see also Gubrium \& Holstein, 1999). Nurses not only tend to support dependent behaviors (see also Baltes, 1996), but they also use patronizing talk as well as a number of deflecting discursive strategies in dealing with residents' emotional rather than care needs (such as ignoring them or referring the older person to someone else who is in charge).

In narrative terms, this line of reasoning makes clear that older adults might be "storyotyped" in certain everyday social interactions (Randall, 1995, p. 57). Rather than paying attention to the needs of the older persons themselves, expectations about older adults and the care they need guide the conversations. The life stories of older adults might thus become saturated with expectations about old age. In effect, older adults may even become de-storied, with their unique life-narratives scarcely listened to, let alone be honored. Their identity is to that degree foreclosed upon in everyday interactions.

\section{Structural-societal factors}

Interpersonal relations do not exist outside of the macro environment of societal structures and ideologies. In a Foucauldian sense, discourse refers to sets of institutional and cultural systems which provide meaning, map out the space in which social practices are made possible, and constitute "official" knowledge or truth (Foucault, 1970,
1974). From a Foucauldian perspective, discourses provide the frameworks in which people order the world and from which they derive their subjectivity. Discourses have their unique array of resources and restrictions, of templates and practices, for the self-storying that people do - or are pressured to do (Holstein \& Gubrium, 2000).

In the field of aging, discourse provides us with a set of age-appropriate-that is, normative-expectations and identities (Tulle \& Mooney, 2002). The dominant discourse in Western societies is one of aging as decline (Gullette, 2004). Even though the association of aging with decline appears to be all too natural, it is also the result of dominant discursive practices in the medical sciences, mass media, social policies, and sometimes even in gerontological knowledge itself (Westerhof \& Tulle, 2007).

These discursive practices are objectified in societal structures. Kohli (1985) has argued that, as a result of the use of chronological age boundaries in social policies and legislation, the life course has, itself, become a societal institution. As such, it is constructed mainly around the standard tripartite structure of education-work-retirement that characterizes the structure of social relations among persons of different ages within our society, as well as the temporal structure of an individual's life. As a result, old age is construed as a separate life phase. In addition, structural lag theory contends that the fact that many people grow old in contemporary society is a historically new phenomenon (Riley, Kahn, \& Foner, 1994). Society lags behind in providing meaningful roles for older persons. Critical gerontology has even put forward the thesis that although the social policies of the welfare state - including retirement, health and housing policies - may have alleviated poverty and hardship among older persons, they have had the side effect of putting older people in a situation of "structured dependency" (Townsend, 1981).

The historically changing dominant discourse, plus the related structural position of older people in our society, provides the background to which older people story their lives (Holstein \& Gubrium, 2000). Older persons incorporate the experiences that are structured both by the dominant discourse and by their societal position into their own life stories, thus coloring the narrative that they weave about who they are and where their life is headed (Westerhof, 2001). The dominant discourse of aging as decline in combination with old age as a separate life phase that lacks meaningful roles or even brings structured dependency might contribute to narrative foreclosure: aging might be experienced not in terms of actively growing old but of passively getting old - merely living out the story with a lack of meaningful commitments that has been imposed on older persons in general.

However, more recent and, in particular, postmodern theories have argued that the societal construction of later life has changed (Featherstone \& Hepworth, 1995; Gergen \& Gergen, 2000; Gilleard \& Higgs, 2000). The increase in life expectancy - and in part also the decrease in the age of retirement - during the past decades have created a new phase of life that provides new possibilities, insofar as it is characterized by a freedom from responsibilities in family life and work. New meanings of aging have emerged in relation to the change from a production-oriented economy to a 
consumerist-oriented economy (Gilleard \& Higgs, 2000). The retirement phase is no longer construed as a period of disengagement from society, but as a period of active reengagement and consumption, leading some to speak of a prolonged midlife style (Featherstone \& Hepworth, 1995). New meanings have also emerged in relation to the change from a standardized to a choice biography (Liefbroer \& Dykstra, 2000): individuals are held more and more responsible for making their own choices which have an effect on their life course development rather than being provided with pre-structured choices provided by social policies of the welfare state.

Although one might argue that these new meanings of aging provide the background for life stories with less NF, three qualifications have to be made. First, these new meanings relate mainly to the third phase of life, thereby leaving the dominant discourse of decline to the fourth age as a period of increasing physical decline and, in this respect, still not eroding it (Andrews, 1999; Blaikie, 1999). Second, the possibilities provided by the new discourse on aging do not have an equal social distribution, but are rather structured by gender, class, and ethnicity (e.g., Krause, 2000). Third, the focus on prolonged midlife, consumerism, and individual responsibility may have its side-effects as well, in particular when older persons feel that they cannot live up to these expectations. For example, stories which highlight dependency or transcendence are still not valued well in our society. Paradoxically, this might result in giving up, and thus in NF.

\section{Conclusion and discussion}

In this paper we have outlined NF as a new concept within narrative gerontology. Old age is the period to draw life to a close in the face of death. It may thus be the phase where NF counts the most, especially as there is less time left to undo regretted choices (Timmer, Westerhof, \& Dittmann-Kohli, 2005). However, one central assumption of narrative gerontology is that identity development does not stop at any age but may well expand to the last moments of one's life. As in the case of Mr. Watanabe, it never appears too late to add a new meaningful storyline to one's life.

From a psychological perspective, we have seen that phases of openness and stability may alternate throughout the life course and that even stability still needs a selfing process of interpretation and meaning making. Hence, NF only occurs when the selfing process stops. From a sociological perspective, we have identified several interpersonal and societal factors that might contribute to NF. The narrative study of lives, and the study of NF in particular, should thus be conducted in an interdisciplinary framework.

Depression and anxiety are major health problems in later life. On the basis of this review, it can be concluded that narrative foreclosure may have significant consequences for mental health in later life. The need to adjust to change and loss is one of the most important and difficult developmental tasks that older adults face (Erikson, 1968). Change is an inescapable part of life. As we have seen, the confrontation with changes and critical life events requires not only the integration of these events in one's current life-story but a revision of underlying narrative schemata as well. This process may become particularly challenging if dominant societal structures, cultural stories, and social interactions are not supportive to this revision. If older adults fail to, or are not able to revise their life-stories, a sense of existential despair may arise (Freeman, 2011). That is, the conviction arises that it simply is too late to live meaningfully, along with the experience that one's future has 'become stripped of new possibilities, emptied of new opportunities for self-renewal' (Freeman, 2011, p. 13). This realization may play an important role in the development of depression and anxiety.

The next challenge will be to study NF empirically. We are currently developing and validating a scale measuring NF. A reliable measure of NF will allow two interesting lines of investigation. Firstly, by using this instrument in larger population studies, it will be possible to study whether NF is indeed related to the intrapersonal and social-cultural factors which we have proposed in this paper, and whether $\mathrm{NF}$ is indeed a mediating factor between major life-events and depression. Secondly, it will be relevant to study NF within the context of therapy. The despair and depression that result from NF may be reasons for older adults to seek counseling. Life-review therapy (Westerhof, Bohlmeijer \& Webster, 2010, Cappeliez, 2002) is especially aimed at helping older adults in revising life-stories and finding new meaning in life. It has been found to be effective in reducing depression with older adults and enhancing meaning in life (Bohlmeijer, Smit, \& Cuijpers, 2003; Bohlmeijer, Westerhof, \& Jong, 2008; Westerhof et al., 2010). An important question is whether the reduction of NF, i.e. a reopening of one's story, is indeed a factor that mediates the positive outcomes of lifereview therapy with older adults. For example, Tromp (2011) found positive effects of life-review on coherence and integration in autobiographical memories of nursing home residents. He concluded that life-review can lead to renewed narrative openness by enhancing stories that focus on aspects of gerotranscendence (Tornstam, 1996). However these claims still have to be substantiated.

Narrative gerontology has not failed to stress that narratives provide a balance between individual agency and sociocultural structures (Westerhof, 2001). We would argue, therefore, that there are no deterministic relations between the psychological and sociological factors considered here. NF only exists within a certain constellation of personal, social, and societal characteristics, drawn together in a mutually dependent system. Hence, it remains a challenge to understand exactly what inspires people to authentically open up their story - as in the case of Mr. Watanabe - or, in the case of $\mathrm{Mr}$. Stevens, to leave the book closed: the book of love.

\section{References}

Andrews, M. (1999). The seductiveness of agelessness. Ageing and Society, 19, $301-318$.

Baltes, M. M. (1996). The many faces of dependency in old age. New York: Cambridge University Press.

Birren, J., Kenyon, G., Ruth, J. -E., Schroots, J., \& Svensson, T. (1996). Aging and biography: Explorations in adult development. New York: Springer.

Blaikie, A. (1999). Ageing and popular culture. Cambridge: Cambridge University Press.

Bohlmeijer, E., Smit, F., \& Cuijpers, P. (2003). Effects of reminiscence and lifereview on late-life depression: A meta-analysis. International Journal of Geriatric Psychiatry, 18, 1088-1094.

Bohlmeijer, E. T., Westerhof, G. J., \& Jong, Emmerik-de (2008). The effects of a new narrative life-review intervention for improving meaning in life in 
older adults: Results of a pilot project. Aging $\mathcal{E}$ Mental Health, 12, 639-646.

Brockmeier, J. (2000). Autobiographical time. Narrative Inquiry, 10, 51-73. Bruner, J. (1990). Acts of meaning. Cambridge: Harvard University Press.

Butler, R. N. (1963). The life-review: An interpretation of reminiscence in the aged. Psychiatry, 26, 65-76.

Caporael, L. R., \& Culbertson, G. H. (1986). Verbal response modes of baby talk and other speech at institutions for the aged. Language $\mathcal{E}$ ' Communication, 6, 99-112.

Cappeliez, P. (2002). Cognitive-reminiscence therapy for depressed older adults in day hospital and long-term care. In J. D. Webster, \& B. K. Haight (Eds.), Critical advances in reminiscence work: From theory to application (pp. 300-313). New York: Springer.

Cuddy, A. J. C., \& Fiske, S. T. (2001). Doddering but dear: Process, content, and function in stereotyping of older persons. In T. D. Nelson (Ed.), Ageism: Stereotyping and prejudice against older persons (pp. 3-26). Cambridge, MA: MIT Press.

Erikson, E. H. (1950). Childhood and society. New York: W.W. Norton.

Erikson, E. H. (1968). Identity: Youth and crisis. New York: W.W. Norton.

Erikson, E. H. (1982). The life cycle completed. New York: W.W. Norton.

Featherstone, M., \& Hepworth, M. (1995). Images of positive ageing: A case study of retirement choice magazine. In M. Featherstone, \& A. Wernick (Eds.), Images of ageing: Cultural representations of later life (pp. 29-48). London: Routledge.

Foucault, M. (1970). L'orde du discourse. Paris: Gallimard.

Foucault, M. (1974). The order of things: An archaeology of the human sciences. London: Tavistock.

Freeman, M. (1991). Rewriting the self: development as moral practice. In M. Tappan, \& M. Packer (Eds.), Narrative and storytelling: Implications for understanding moral development. San Francisco: Jossey-Bass.

Freeman, M. (2000). When the story's over: narrative foreclosure and the possibility of self-renewal. In M. Andrews, S. Slater, C. Squire, \& A. Treacher (Eds.), Lines of narrative: Psychosocial perspectives (pp. 245-250). Toronto: Captus University Publications.

Freeman, M. (2011). Narrative foreclosure in later life. In G. Kenyon, E. T. Bohlmeijer, \& W. R. Randall (Eds.), Storying later life; issues, investigations, and interventions in narrative gerontology (pp. 3-19). New York: Oxford University Press.

Gergen, K. J., \& Gergen, M. M. (2000). The new aging: Self construction and social values. In K. W. Schaie, \& J. Hendricks (Eds.), The evolution of the aging self: The societal impact on the aging process (pp. 281-306). New York: Springer.

Giles, H., Coupland, N., Coupland, J., Williams, A., \& Nussbaum, J. (1992). Intergenerational talk and communication with older people. International Journal of Aging \&' Human Development, 34, 271-292.

Gilleard, C., \& Higgs, P. (2000). Cultures of ageing: Self, citizen and the body. Harlow: Prentice Hall.

Grainger, K. (2004). Communication and the institutionalized elderly. In J. F. Nussbaum, \& J. Coupland (Eds.), Handbook of communication and aging research (pp. 479-497). Mahwah, NJ: Lawrence Erlbaum.

Grotevant, M. D., \& Cooper, C. R. (1986). Individuation in family relationships: A perspective on individual differences in the development of identity and role taking skill in adolescents. Human Development, 29, 82-100.

Gubrium, J. F., \& Holstein, J. A. (1999). The nursing home as a discursive anchor for the ageing body. Ageing and Society, 19, 519-538.

Gullette, M. (2004). Aged by culture. Chicago: The University of Chicago Press.

Habermas, T., \& Bluck, S. (2000). Getting a life: The emergence of the life story in adolescence. Psychological Bulletin, 126, 748-769.

Holstein, J., \& Gubrium, J. (2000). The self we live by: Narrative identity in a postmodern world. New York: Oxford University Press.

Hummert, M. L. (1994). Stereotypes of the elderly and patronizing speech. In M. L Hummer, J. M. Wiemann, \& J. F. Nussbaum (Eds.), Interpersonal communication in older adulthood (pp. 162-184). Thousand Oaks, CA: Sage.

Kemper, S., \& Harden, T. (1999). Experimentally disentangling what's beneficial about elderspeak from what's not. Psychology and Aging, 14, 656-670.

Kenyon, G., Bohlmeijer, E. T., \& Randall, W. R. (2011). Storying later life; issues, investigations, and interventions in narrative gerontology. New York: Oxford University Press.

Kenyon, G., Clark, P., \& de Vries, B. (2001). Narrative gerontology, theory, research and practice. New York: Springer Publishing Company.

Kite, M. E., \& Johnson, B. T. (1988). Attitudes towards older and younger adults: A meta-analysis. Psychology and Aging, 3, 233-244.

Kohli, M. (1985). Die Institutionalisierung des Lebenslaufs. Kölner Zeitschrift für Soziologie und Sozialpsychologie, 37, 1-29.

Krause, N. (2000). Commentary: Are we really entering a new era of aging? In K. W. Schaie, \& J. Hendricks (Eds.), The evolution of the aging self: The societal impact on the aging process (pp. 307-318). New York: Springer.
Liefbroer, A. C., \& Dykstra, P. A. (2000). Levenslopen in verandering: Een studie naar ontwikkelingen in de levenslopen van Nederlanders geboren tussen 1900 en 1970 [Life courses in change: A study on developments in life courses of Dutch persons born between 1900 and 1970]. Den Haag: SDU.

Marcia, J. (1966). Development and validation of ego-identity status. Journal of Personality and Social Psychology, 3, 551-558.

Marcia, J. E. (1980). Identity in adolescence. In J. Adelson (Ed.), Handbook of adolescent psychology (pp. 159-187). New York: Wiley.

McAdams, D. (1996). Personality, modernity and the storied self: A contemporary framework for studying persons. Psychological Inquiry, 7, 295-321.

McAdams, D. (2008). Personal narratives and the life story. In John, Robins, \& Pervin (Eds.), Handbook of personality: Theory and research (3rd ed). New York: Guilford Press.

Morson, G. (1994). Narrative and freedom: The shadow of time. New Haven: Yale University Press.

Polkinghorne, D. (1998). Narrative knowing and the human sciences. Albany: State University of New York Press.

Randall, W. (1995). The stories we are: An essay on self-creation. Toronto: University of Toronto Press.

Randall, W., \& McKim (2008). Reading our lives, the poetics of growing old. New York: Oxford University Press.

Reker, G., \& Chamberlain, L. (2000). Exploring existential meaning: optimizing human development across the life-span. Thousand Oaks, California: Sage.

Ricoeur, P. (1991). Life in quest of narrative. In D. Wood (Ed.), On Paul Ricoeur: Narrative and interpretation (pp. 20-33). London: Routledge.

Riley, M. W., Kahn, R. L., \& Foner, A. (1994). Age and structural lag: Society's failure to provide meaningful opportunities in work, family, and leisure. New York: Wiley.

Ryan, E. B., Hummert, M. L., \& Boich, L. H. (1995). Communication predicaments of aging: Patronizing behavior toward older adults. Journal of Language and Social Psychology, 14, 144-166.

Skultety, K. M., \& Whitbourne, S. K. (2004). Gender differences in identity processes and self-esteem in middle and later adulthood. Journal of Women E' Aging, 16, 175-188.

Stephen, J., Fraser, E., \& Marcia, J. (1992). Moratorium-achievement (Mama) cycles in lifespan identity development: value orientations and reasoning system correlates. Journal of Adolescence, 15, 283-300.

Timmer, E., Westerhof, G. J., \& Dittmann-Kohli, F. (2005). "When looking back on my past life I regret...": Retrospective regret in the second half of life. Death Studies, 29, 625-644.

Tornstam, L. (1996). Gerotranscendence: A theory about maturing in old ag. Journal of Aging and Identity, 4, 155-166.

Townsend, P. (1981). The structured dependency of the elderly: Creation of social policy in the twentieth century. Ageing and Society, 1, 5-28.

Tromp, T. (2011). Older adults in search of new stories: Measuring the effects of life review on coherence and integration in autobiographical narratives. In G. Kenyon, E. T. Bohlmeijer, \& W. R. Randall (Eds.), Storying later life; issues, investigations, and interventions in narrative gerontology (pp. 252-272). New York: Oxford University Press.

Tulle, E., \& Mooney, E. (2002). Moving to 'age-appropriate' housing: Government and self in later life. Sociology, 36, 683-701.

Westerhof, G. J. (2001). "I'm afraid that I'll lose my job before I retire": Personal narratives about employment and the social structures of the life course. Hallym International Journal of Aging, 3, 55-79.

Westerhof, G. J. (2005). Oud en nieuw: Het levensverhaal van ouderen in een veranderende samenleving [Old and new: The life story of older persons in a changing society]. In P. Klep, C. Hoetink, \& T. Emons (Eds.), Persoonlijk verleden: Over geschiedenis, individu en identiteit (pp. 59-73). Amsterdam: Aksant.

Westerhof, G. J. (2009). Identity construction in the third age: The role of self-narratives. In H. Hartung, \& R. Maierhofer (Eds.), Narratives of lives: Mediating age (pp. 55-69). Münster: LIT.

Westerhof, G. J., Bohlmeijer, E. T., van Beljouw, M. J., \& Pot, A. M. (2010). Improvement in personal meaning mediates the effects of a life-review intervention on depressive symptoms in a randomized controlled trial. The Gerontologist, doi:10.1093/geront/gnp168.

Westerhof, G. J., \& Tulle, E. (2007). Meanings of ageing and old age: Discursive contexts, social attitudes and personal identities. In J. Bond, S. Peace, F. Dittmann-Kohli, \& G. J. Westerhof (Eds.), Ageing in society (pp. 235-254). (3rd Ed.). London: Sage.

Whitbourne, S. K. (1986). The me I know: A study of adult identity. New York: Springer-Verlag.

Williams, A., \& Nussbaum, J. F. (2001). Intergenerational communication across the life span. Mahwah, $\mathrm{NJ} /$ London: Lawrence Erlbaum.

Wong, P. T. (1995). The processes of adaptive reminiscence. In B. K. Haight, \& J. D. Webster (Eds.), The art and science of reminiscing: Theory, research, methods, and applications (pp. 23-35). Taylor \& Francis. 